\title{
Farlige forbindelser?
}

Tverrfaglig orienterte, medisinsk skolerte lesere kan for tiden følge med på fremveksten av en ny vitenskapelig forståelse av den menneskelige biologien. Den springer ut i grensesonene mellom endokrinologi, immunologi, nevrofysiologi, psykologi, genetikk og epigenetikk (1-7) og favner i tillegg epidemiologiske studier fra en rekke kliniske fag, blant disse også kardiologi og psykiatri. Samlet sett bærer denne nye kunnskapen bud om sammenhenger som overskrider tradisjonelle grenser og utvisker vante skillelinjer i medisinen.

Gunnar Einvik og medarbeidere spør i dette nummer av Tidsskriftet om depresjon og kardiovaskulær sykdom henger sammen (8). Svaret deres bygger på en litteraturoversikt over en spesiell berøringsflate innen medisinen, mellom den såkalt mentale lidelsen depresjon, og en sykdom som tradisjonelt oppfattes som somatisk, nemlig kardiovaskulaer sykdom. Og konklusjonen deres er: Ja, her er det en sammenheng, og den bør leger være oppmerksomme på.

Forfatterne bygger sitt utvalg av artikler om psykiatrisk og somatisk epidemiologi på egen faglig erfaring innen emnet depresjon og kardiovaskulær sykdom. Det er interessant at de bruker entallsformen emnet i stedet for flertallsformen emner, som man skulle forvente gitt forfatternes ulike bakgrunn i kardiologi og psykiatri. Forfatterne leser og drøfter altså disse artiklene ut fra antakelsen om at det komorbiditetsmønsteret de har observert i sin kliniske hverdag, kan være uttrykk for noe mer enn en statistisk sammenheng. En av sammenhengene som de finner bekreftet, er at både depresjon og kardiovaskulær sykdom er assosiert med kronisk, systemisk inflammasjon.

Den innledningsvis omtalte nye empiriske kunnskapen handler om denne og liknende sammenhenger. Kronisk, systemisk inflammasjon synes nemlig også å ligge «bak» andre medisinske fenomener som hver for seg ser ut til å stå i farlige forbindelser til hjerte- og karsykdommer generelt - og til hverandre. Noen eksempler er preeklampsi, periodontale sykdommer og metabolsk syndrom (9-11). Men mye tyder på at rekken av inflammasjonsbetingede sykdommer er lengre. Antallet studier som utpeker inflammasjon som en årsak til tilsynelatende atskilte sykdommer, har økt rask de siste årene. Samtidig som kronisk, systemisk inflammasjon fremtrer som bindeledd, inngår den påviselig også i større mønstre av patogene prosesser som danner grunnlag for komplekse bilder av kronisk sykelighet. Disse mønstrene omfatter feilfunksjoner i hormonsystemet, immunsystemet og sentralnervesystemet (1-4), og de kan innebære endringer på genetisk nivå (5-7).

Den nye kunnskapen omfatter også en stadig økende dokumentasjon av sammenhenger mellom disse mønstrene av funksjonsforstyrrelser og sykelighet på den ene siden, og belastende sosiale forhold og personlige relasjoner på den andre $(1-5,10,11)$. Med andre ord: Vond og vanskelig erfaring gjennom livet viser seg stadig mer tydelig å stå i sammenheng med et vidt spekter av sykdommer. Den flerfaglig sammensatte kunnskapen synes å bære i seg en ny og medisinsk sett viktig erkjennelse: Det å måtte leve med langvarig konflikt, nedverdigelse, trussel, diskriminering og stigmatisering kan synes å utløse patogene prosesser som kan skape og bidra til sykdom eller forverre forløpet av sykdom. Sagt på en annen måte: Slike sosiale og relasjonelle forhold danner farlige for- bindelser. Virkningen, slik den fremgår av de forannevnte studiene, kan være omfattende og sammensatt. Slike forhold synes å svekke livsbevarende funksjoner slik som den medfødte og ervervede immunitet; de kan igangsette eller opprettholde systemiske inflammasjoner; de kan fremme og forsterke infeksjoner; og de kan utløse epigenetiske endringer $(1-7,10,11)$.

I medisinens anerkjennelse av denne nye kunnskapen ligger det en vitenskapsteoretisk utfordring. Den handler om å gjøre det subjektive fenomenet erfaring gjeldende i den medisinske kunnskapsproduksjonen. Bare en annen epidemiologi enn den tradisjonelle kan favne det erfarende subjektet (12). Bare et gyldighetsbegrep som også rommer subjektet, kan være adekvat for å forstå virkningen av personlig erfaring. Anerkjennelsen innbærer også et etisk imperativ til både den medisinske forskeren og klinikeren: Møt mennesket på en adekvat måte, altså med tilnærminger og med kunnskap som yter menneskets vesen rettferd! Som sosialt vesen er mennesket en syntese av biologi og historie. Mennesker har evnen til å skape og videreføre mening ut fra erfaring og liv i samliv med andre. Kan vi klare å utvikle en metodologi som svarer til slike krav?

\section{Anna Luise Kirkengen}

anlui-k@online.no

Anna Luise Kirkengen, (f. 1946) er professor II i allmennmedisin ved Universitetet i Tromsø og ved Norges teknisk-naturvitenskapelige universitet Trondheim, og seniorforsker ved Senter for helsefremmende arbeid, Akershus universitetssykehus.

\section{Oppgitte interessekonflikter: Ingen}

\section{Litteratur}

1. Kiecolt-Glaser JK, Gouin J-P, Hantsoo L. Close relationships, inflammation, and health. Neurosci Biobehav Rev 2009, doi: 10.1016/j.neubiorev.2009.09.003.

2. Irwin MR. Human psychoneuroimmunology: 20 years of discovery. Brain Behav Immun 2008: 22: 129-39.

3. Shonkoff JP, Boyce WT, McEwen BS. Neuroscience, molecular biology, and the childhood roots of health disparities. Building a new framework for health promotion and disease prevention. JAMA 2009; 301: 2252-9.

4. Juster RP, McEwen BS, Lupien SJ. Allostatic load biomarkers of chronic stress and impact on health and cognition. Neurosci Biobehav Rev 2009; e-publisert 12.10.2009.

5. Epel ES, Lin J, Dhabhar FS et al. Dynamics of telomerase activity in response to acute psychological stress. Brain Behav Immun 2009; e-publisert 16.12.2009.

6. Gluckman PD, Hanson MA, Cooper C et al. Effect of in utero and early-life conditions on adult health and disease. N Engl J Med 2008; 359: 61-73.

7. Jirtle RL, Skinner MK. Environmental epigenomics and disease susceptibility. Nat Rev Genet 2007; 8: 253-62.

8. Einvik G, Dammen T, Omland T. Depresjon og kardiovaskulær sykdom - er det en sammenheng? Tidsskr Nor Legeforen 2010; 130: 729-32.

9. Magnussen EB, Vatten LJ, Lund-Nilsen TI et al. Prepregnancy cardiovascular risk factors as predictors of pre-eclampsia: population based cohort study. BMJ 2007; 335: 978-86.

10. Sabbah W. Watt RG. Sheiham A et al. Effects of allostatic load on the social gradient in ischaemic heart disease and periodontal disease: evidence from the Third National Health and Nutrition Examination Survey. BMJ 2008; 62: 415-20.

11. Brunner EJ, Chandola T, Marmot MG. Prospective effect of job strain on general and central obesity in the Whitehall II Study. Am J Epidemiol 2007: 165: 828-37.

12. Kirkengen AL, Getz L, Hetlevik I. En annen kardiovaskulær epidemiologi. Tidsskr Nor Legeforen 2008; 128: 2181-4 